$$
\begin{aligned}
& \text { pla تشخيص مولكولى عامل طاعون بر اساس زن } \\
& \text { خاطره كبيرى' و كيوان مجيدزاده } \\
& \text { اكروه ميكروبيولوزى، دانشعاه آزاد اسلامى واحد تهران شمال، تهران، ايران؛ 'مركز تحقيقات زيست فن آورى تسنيم، دانشكده يزشكى، دانشعاه علوم يزشكى آجا، } \\
& \text { تهران، ايران. } \\
& \text { k.kabiri@iau-tnb.ac.ir نويسنده مسئول: خاطره كبيرى، }
\end{aligned}
$$$$
\text { קكيده. يرسينيا يُتيس عامل بيمارى طاعون، باسيلى گرم منفى متعلق به تيره انتروباكترياسه است. تشخيص اين اركانيسم بر اساس روشهاى كلاسيك وقت }
$$

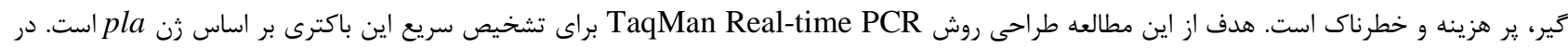

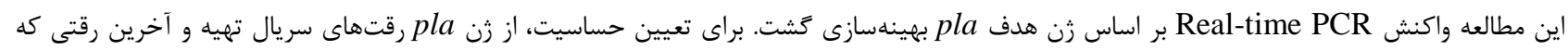

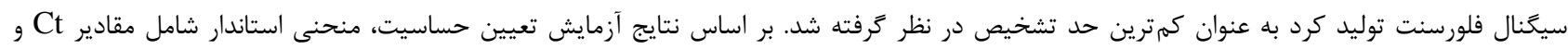

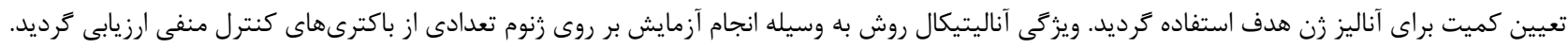

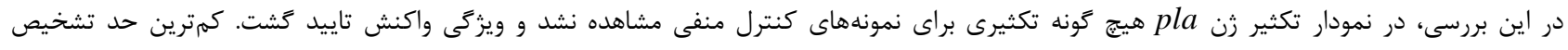

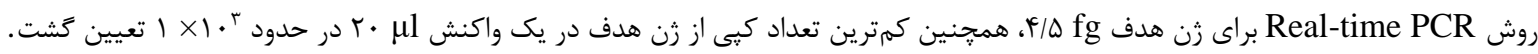$$
\text { وازههاى كليدى. ريل تايم يى سى آر، كنترل منفى، منحنى استاندارد، ويزَگى، يرسينيا پٍتيس }
$$

\title{
The molecular detection of the causative agent of plague on the basis of the pla gene
}

\author{
Khatereh Kabiri ${ }^{1}$ \& Keivan Majidzadeh \\ ${ }^{1}$ Department of Microbiology, North Tehran Branch, Islamic Azad University, Tehran, Iran, ${ }^{2}$ Tasnim Biotechnology \\ Research Center (TBRC), AJA University of Medical Sciences, Tehran, Iran \\ Correspondent author: Khatereh Kabiri, k.kabiri@iau-tnb.ac.ir
}

\begin{abstract}
Yersinia pestis, a gram-negative rod belonging to the Enterobacteriaceae family, is the causative agent of plague. Classical methods of detecting the organisms are time-consuming, expensive and dangerous. The aim of the study was to design a Real-time PCR assay on the basis of the pla gene of Yersinia pestis. In this research the Realtime PCR test was optimized by using special primers for targeting pla gene. After preparing 10-fold serial dilutions of the pla and their analysis by the assay, the last dilution showing a fluorescent signal was confirmed as the limit of detection (LOD). A standard curve based on the $\mathrm{Ct}$ values was depicted, so the assay was developed to quantify the target gene. The analytical specificity was determined by subjecting the genome of some control negative bacteria to the assay. In this experiment, negative control genomes did not show detectable signals in the assay. The last dilution of pla plasmid which showed a fluorescent signal was $4.5 \mathrm{fg}$. So, the lower detectable copy numbers of the gene in a $20 \mu 1$ PCR reaction was calculated as $1 \times 10^{3}$.
\end{abstract}

Keywords. control negative, Real- time PCR, specificity, standard curve, Yersinia pestis 
علاوه براين، درمان با آنتى بيوتيك يا آلودگى متقاطع با ساير

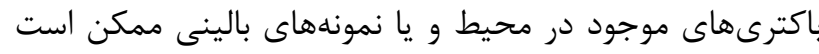
مانع رشد ميكرواركانيسم هدف در محيط كشت شود. مشكلات

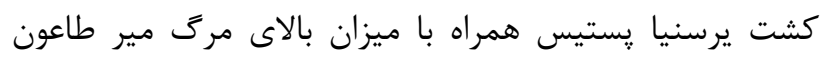
ريوى سبب شده نياز به روشهاى تشخيص سريع اهميت بسزايى ييدا كند. روشهاى مولكولى مدت زمان كمى نياز دارند و غالبا از

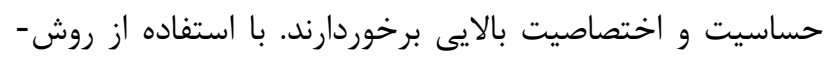

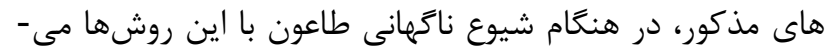
توان تعداد زيادى نمونه را به طور همزمان بررسى نمود؛ در نتيجه سرعت تشخيص و كنترل ييشرفت بيمارى در يك جمعيت بالا مىرود، بنابراين طراحى روشهاى تشخيص سريع جهت شناسايى اين ميكرواركانيسم از اهميت بالايى برخوردار

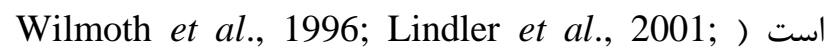
.(O’Hara, 2005; Riehm et al., 2011 ميكروار كانيسم مزبور، داراى يُاسميد انحصارى pPCP1 به طول pb kb است كه زن بيمارىزا pla بر روى آن قرار گرفته است. زن pla فعال كننده يلاسمينوزن است و در اتصال و تهاجم رئماري به سلولهاى ميزبان نقش موثرى دارا است و منحصرا در تمام سويههاى يرسينيا يستيس وجود دارد. در سالهاى اخير روشهايى جهت تشخيص مولكولى يرسينيا گِتيس بر اساس زنهاى

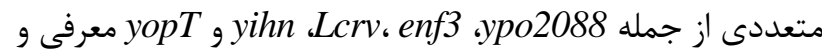
تكامل يافته است، اما تمامى زنهاى مذكور از اختصاصيت يايين برخوردار و يا به دليل قرار گرفتن بر روى يلاسميدهاى مشترى

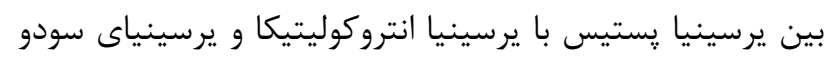
توبركلوزيس جهت هدف كذارى براى تشخيص مناسب ارزيابى

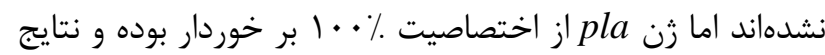

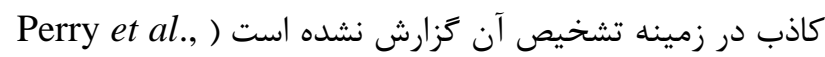
ز 1999; Tomaso et al., 2003; Stewart et al., 2008 اين رو هدف از اين يروهش، طراحى روش Real-Time PCR جهت تشخيص سريع و دقيق زن pla در باكترى يرسينيا يستيس تعيين گرديد.

$$
\text { مواد و روشيا }
$$

زنوم سويهها

در اين مطالعه، زنوم باكترى يرسينيا يستيس از انستيتو پاستور

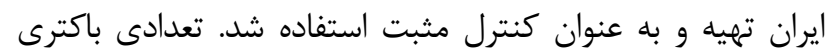
منسوب و غير منسوب به عنوان كنترل منفى انتخاب گرديد كه در جدول ا ذكر شده است. باكترىهاى كنترل منفى همكى به به شكل ليوفيليزه بودند بنابراين ابتدا آنها در محيط (Merck)

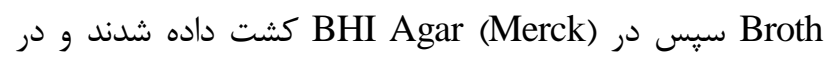

مقلمهـ

يرسينيا پستيس (Yersinia pestis)، باسيلى گرم منفى از تيره انتروباكترياسه است كه براساس توانايى تبديل نيترات به به به بـاسئيس

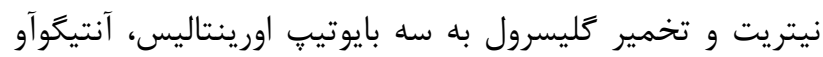

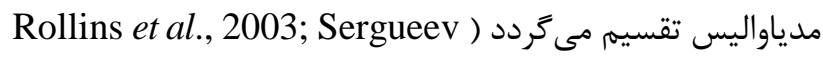

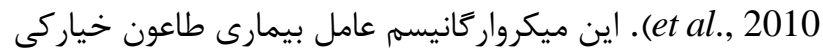

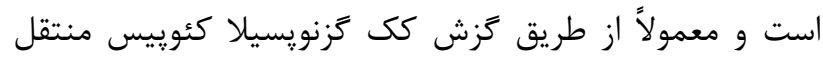
مىشود. يس از انتشار به ريهها رفته و از طريق آئروسل آلوده از

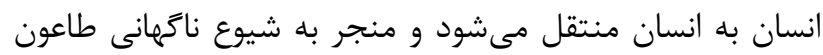

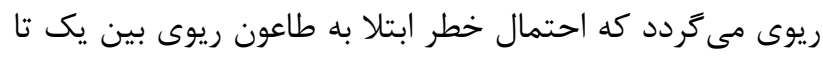

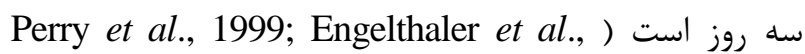
.(1999; Woron et al., 2006; Tomaso et al., 2006 بيمارى طاعون در بسيارى از مناطق آسيا، آفريقا و آمريكا به

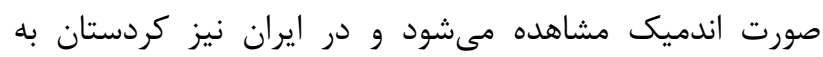

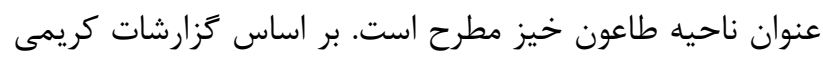

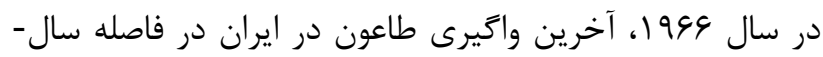

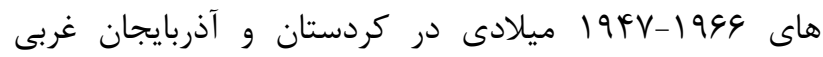
Tomaso et al., 2006; Azizi \& Azizi, ) مشاهده شده است درديان 2010; Riehm et al., 2011

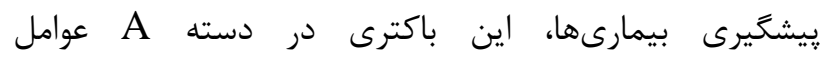

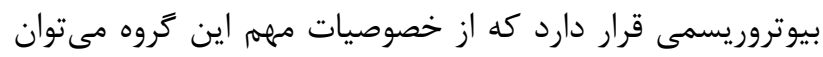

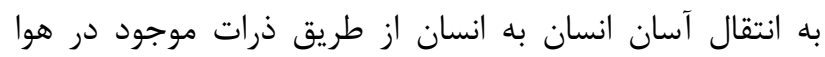
(أئروسل)، نرخ بالاى مرگ و مير، سهولت توليد و انتشار آسان،

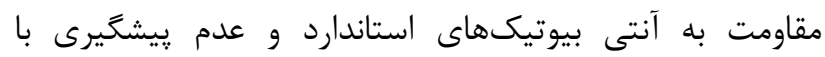
واكسن اشاره كرد. خطرناك بودن اين باكترى سبب شده كه جداسازى و كشت آن تنها در آزمايشخاههاى داراى سطح ايمنى زيستى ل صورت گيرد ) Woron et al., 2006; Kenny et al., .(2008; Sergueev et al., 2010; Riehm et al., 2011 روشهاى تشخيص كلاسيك اين باكترى مانند: تستهاى بيوشيميايى، سرولوزى، حساسيت به باكتريوفاز اختصاصى، رنت رون

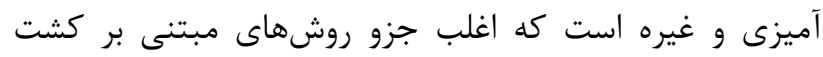
محسوب مى گردد و به سبب رشد كند باكترى بسيار وقت گير و و

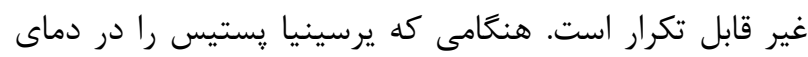

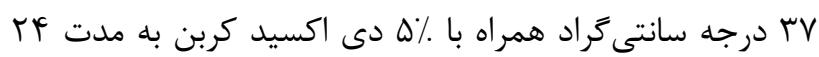

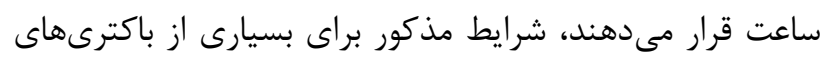
بيمارىزا و مورد توجه در زيزشى مناسب است، بنابراين ممكن است رشد ساير باكترىها نيز در محيط مشاهده شود ( Suzuki et al., 1997; Leal \& Almeida, 1999; Tomaso et al., 2007; Perry et al., 1999; Schofield et al., 2009; .(Filippov et al., 2011 
محاسبه و در برنامه تنظيمات مربوط به منحنى استاندارد وارد گردد. يس از اتمام واكنش، با استفاده از منحنى استاندارد، تعداد نسخهـ

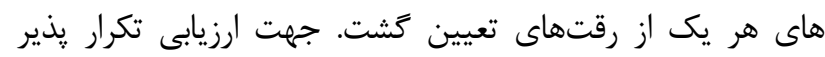

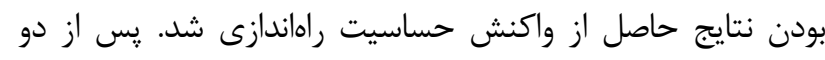

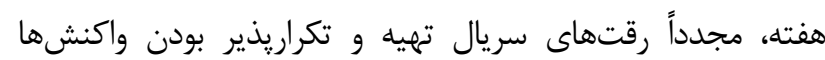
مطابق شرايط ذكر شده بررسى كرديد.

\section{نتايج}

نتايج واكنش نئش

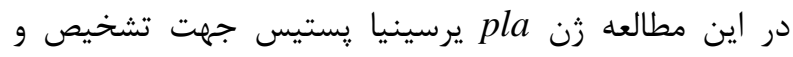

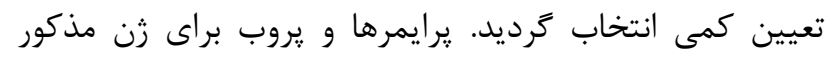

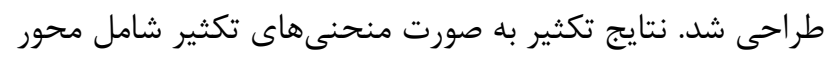

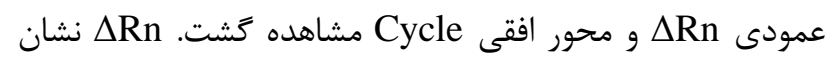

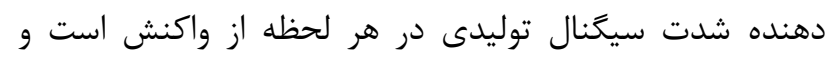

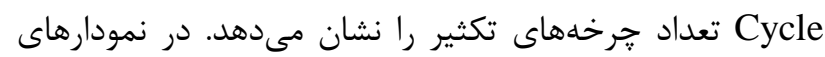

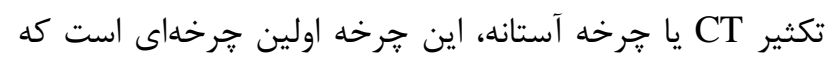

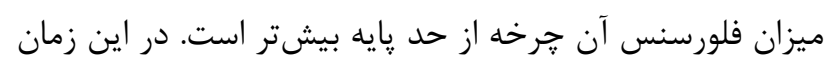

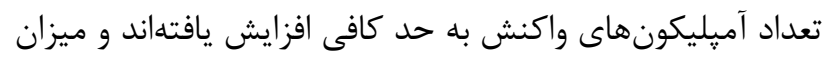

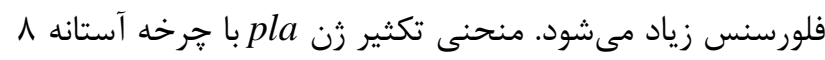

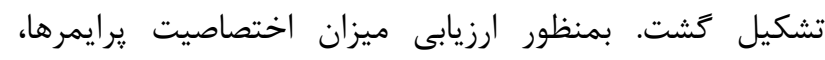

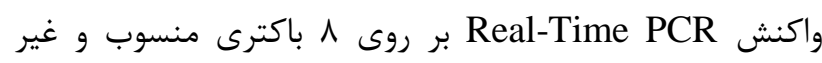
منسوب به عنوان كنترل منفى انجام شد. pla-Real- time PCR واكنش

با استفاده از يرايمرهاى Feverse- و Forward -pla-real

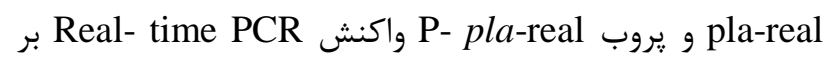
روى DNA زنوميك باكترىهاى كنترل منفى انجام شد. همانطور

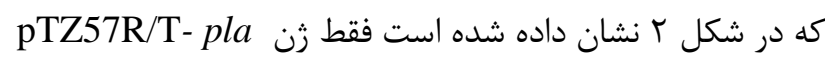
با يرايمرهاى مذكور قابل تكثير بودند.

نتايج تعيين حساسيت

جهت تعيين حساسيت و كمترين حد تشخيص رقتهاى سريال (ده كانه) از زن pTZ57R/T- pla با غلظت

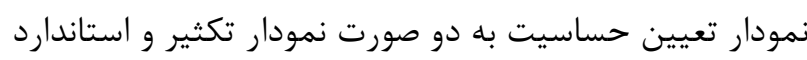
قابل مشاهده است كه در شكلهاى بـ ؤ نشان داده شده است.

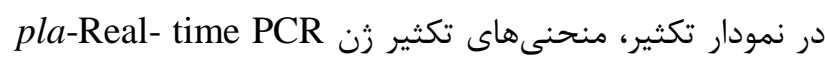
در غلظتهاى مختلف نمايش داده شده است. نمودار استاندارد از

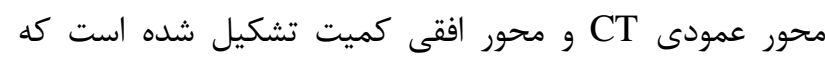

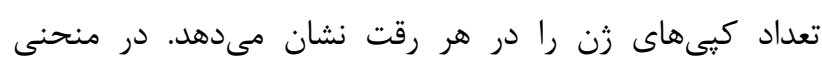

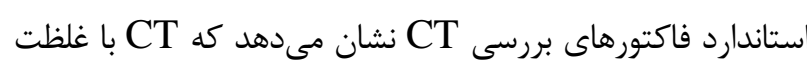

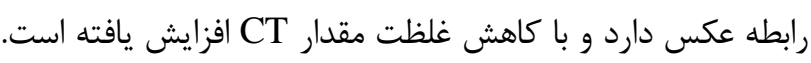

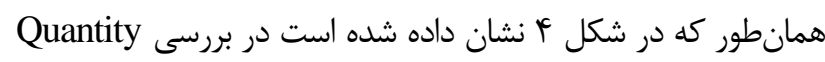

دماى VIV درجه سانتى كراد به مدت IV ساعت در كرمخانه نكمهدارى

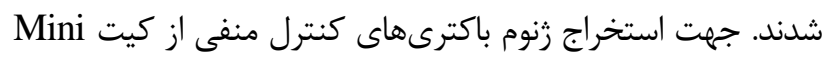
طit (k-31111, K-3112) Extraction طراحى يرايمر و يروب زن pla كه بر روى يلاسميد pPCP1 قرار كرفته است به عنوان

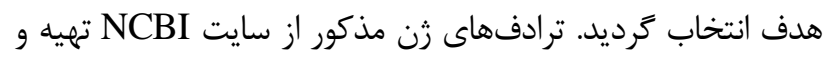
يرايمرها و يروب با استفاده از نرم افزار

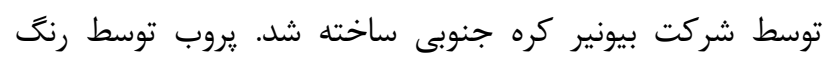

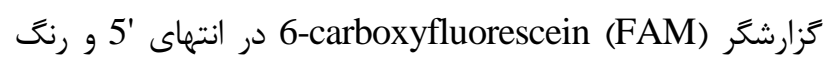

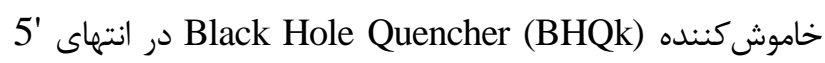
نشانهكذارى كرديد (جدول ()).

واكنش Real-Time PCR جهت ارزيابى زنهاى هدف و تشخيص يرسينيا پستيس، بهينه

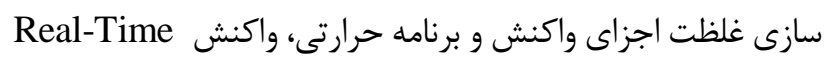

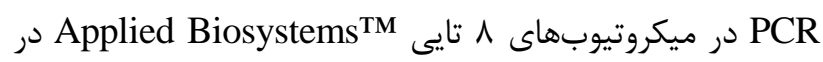

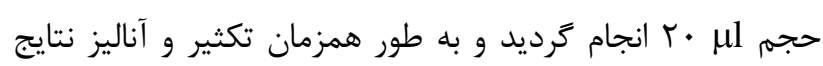
Applied ) 7500 Fast Real-Time PCR توسط دستر ونكان (Biosystems, ABI Premix Ex Taq (2X) يرايمر جلويى و عقبى و تروب (l) ROX (25X)

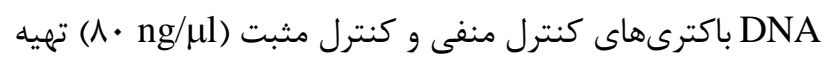
كرديد. همجنين يك واكنش

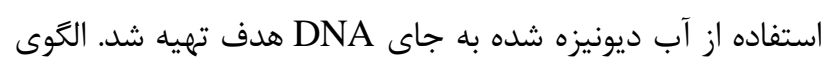

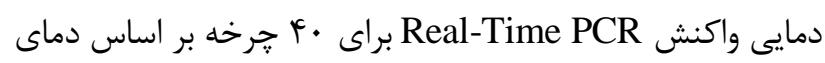

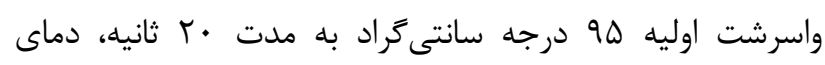
اتصال لها درجه سانتى

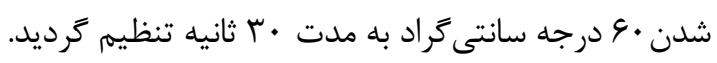

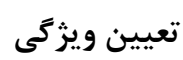
به منظور ارزيابى ويزگى و و اختصاصيت يرايمرها، واكنش

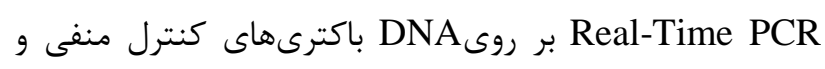

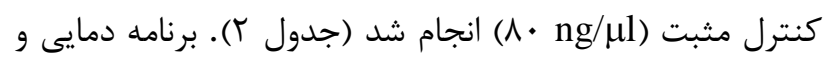
اجزاى واكنش مطابق با شرايط فوق تهيه كرديد.

\section{تعيين حساسيت}

جهت انجام واكنش حساسيت براى تعيين كمترين حد تشخيص

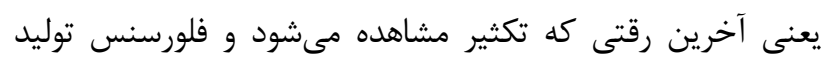

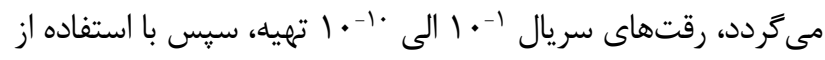

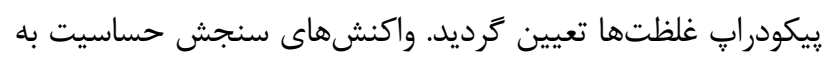
شكل سه تايى براى هر رقت مطابق با اجزاى واكنش و برنامه دمايى ترديى

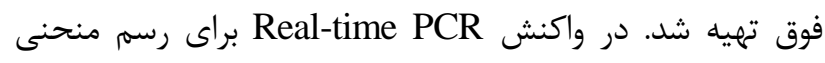

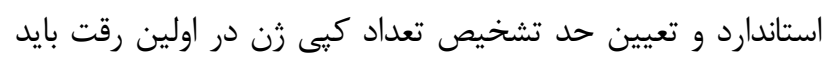


جدول ا- فهرست يرايمر و يروب استفاده شده.

Table 1. The list of primers and probes used.

\begin{tabular}{|c|c|}
\hline نام يرايمر و يروب & ('3 ('5') ترادف \\
\hline F-pla-real & GCTCACGTTATTATGGTAC \\
\hline R-pla -real & TCTCCACTATTCTTATCAATG \\
\hline P-pla -real & ATTAACGCTGGATATTATGTCACACCT \\
\hline
\end{tabular}

جدول r- ليست باكترى هاى استفاده شده جهت سنجش اختصاصيت.

Table 2. The list of bacteria used for specificity assay.

\begin{tabular}{|l|c|}
\hline \multicolumn{1}{|c|}{ نام ميكرو اركانيسا } & ATCC 9290 \\
\hline Shigella sonnei & ATCC 7881 \\
\hline Klebsiella pneumoniae & ATCC 25922 \\
\hline Escherichia coli & ATCC 25051 \\
\hline Bacillus subtilis & ATCC 605 25923 \\
\hline Staphylococcus aureus & ATCC 29212 \\
\hline Enterococcus faecalis & PTCC 1480 \\
\hline Yersinia enterocolitica & ATCC 29833 \\
\hline Yersinia pseudotuberculosis & \\
\hline
\end{tabular}

Amplification plot

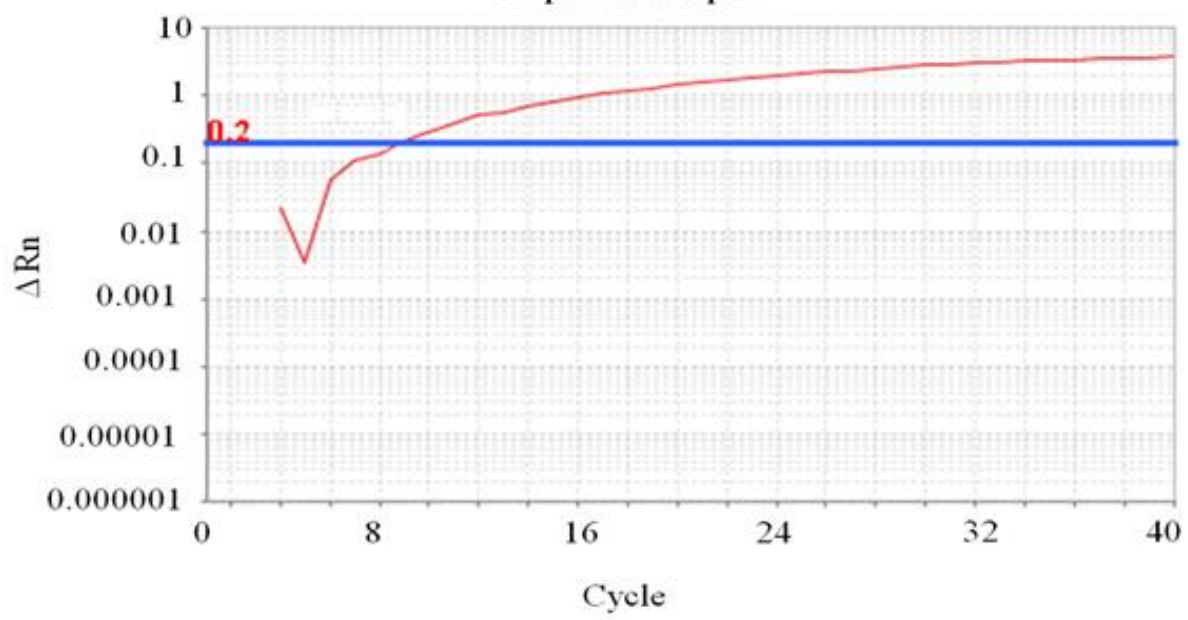

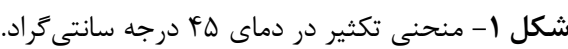

Fig. 1. Amplification curve at $45^{\circ} \mathrm{C}$

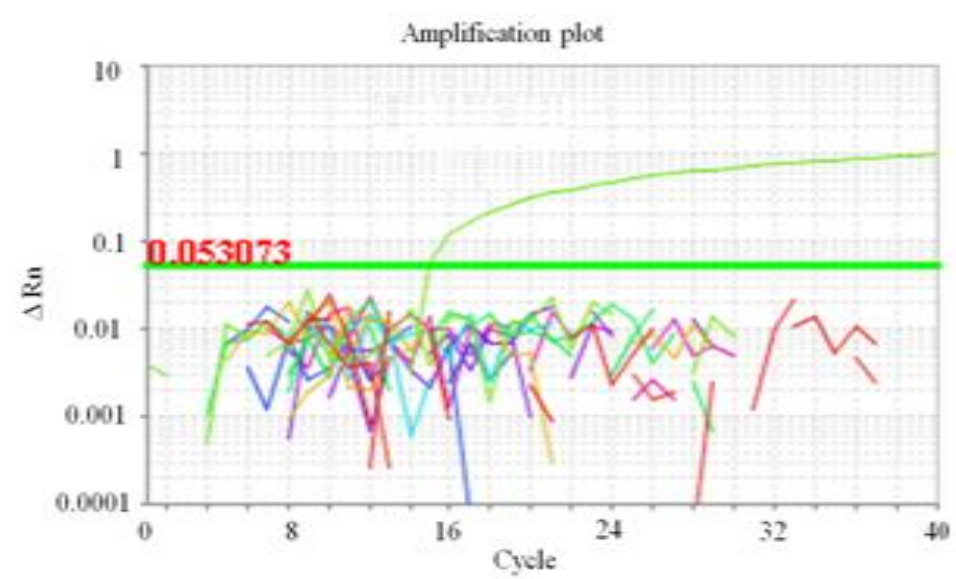

pla-Real- time PCR شكل r- منحنى ويزگ

Fig. 2. Specificity curve of pla-Real- time PCR 


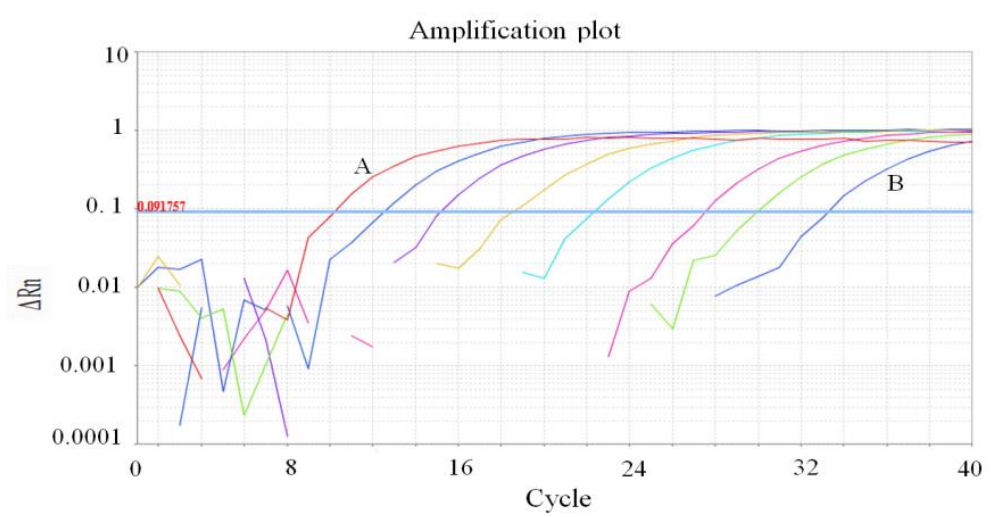

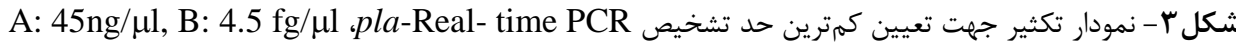

Fig. 3. Amplification curve to determine the limit of detection for pla-Real- time PCR, A: $45 \mathrm{ng} / \mu \mathrm{l}, \mathrm{B}: 4.5 \mathrm{fg} / \mu \mathrm{l}$

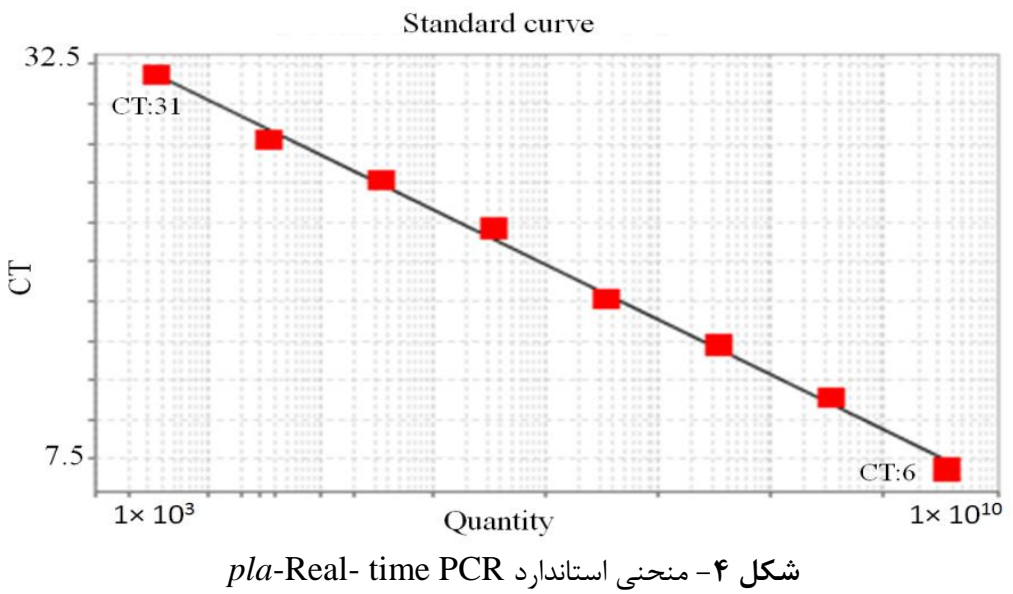

Fig. 4. Standard curve for pla-Real- time PCR

طاعون خيز وجود دارد، در ايران هم اگرجه آخرين گزارشها

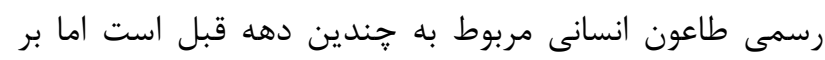
اساس گزارشات اخير انستيتو پاستور ايران هنوز هم كردستان Filippov et al., ) به عنوان ناحيه طاعون خيز مطرح استون (2011; Esamaeili et al., 2013 مولكولى مختلفى براى اين باكترى ارائه شده است كه از

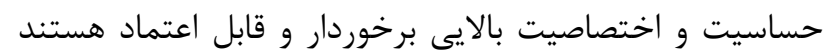
(Loiez et al., 2003; Zhang et al., 2013) مولكولى تشخيص به وسيله Real-time PCR نياز به مراحل بين رنائ يس از PCR مانند: زل الكتروفورز، رنت آميزى با اتيديوم برومايد و تفسير زل با نور ماوراى بنفش ندارد و احتمال آلودگى هاى مقاطع كاهش مى يابد. همجنين در اين روش تكثير و تشخيص اسيد نوكلئيك در يك محيط سربسته صورت زرفته و مى توان مقدار كمى توالى هدف را تعيين نمود ( Drancourt \& Raoult, 2002; Arya et al., 2005; Mackay et al., 2004; Chase et al., 2005; Espy et al., 2006; Ayyadurai et al., 2010; Qu et al., 2010 محققين از Real-time PCR جهت تشخيص باكترى مزبور در

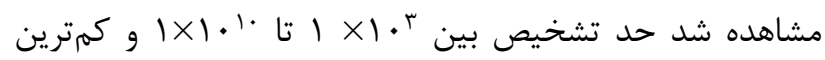

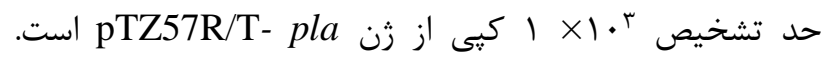

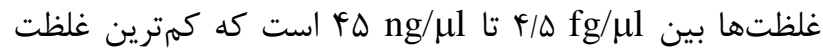

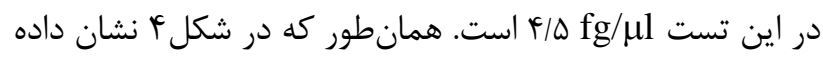
شده است با كاهش غلظت، تكثير ديرتر صورت گرفته و افزايش يافته است. در دهdهاى اخير با معرفى تكنيك Real- time PCR، اين روش جهت شناسايى بسيارى از باكترىها از جمله گونههاى

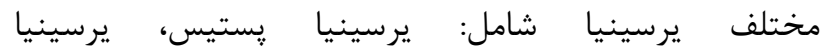

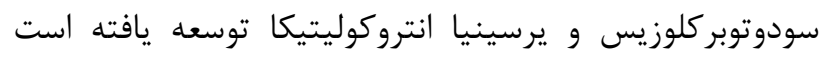
(Matero et al., 2009; Wang et al., 2014) اينكه يرسينيا يستيس در دسته A عوامل بيوتروريسمى قرار گرفته است و از آن در ساخت سلاحهاى زيستى مى ئوان استفاده نمود به عنوان تهديدى براى تمام جهانيان محسوب مى ₹ردد. در حال حاضر در بسيارى از نقاط جهان مناطق برى 
استفاده نمودند. نتايج آنها نشان داد بالاترين اختصاصيت مربوط به

يرسينيا پِتيس ( • (1 درصد) است (Rachwal et al., 2012).

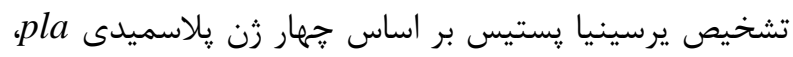

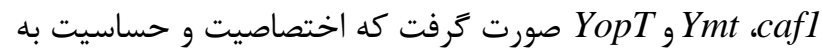
ترتيب . ·1 درصد و از روش Real-time PCR با استفاده از يروب TaqMan براى تشخيص يك زن كروموزومى و سه زن زيلاسميدى استفاده شده

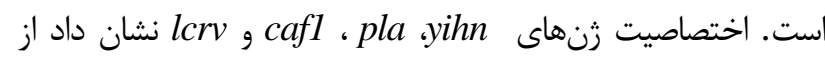

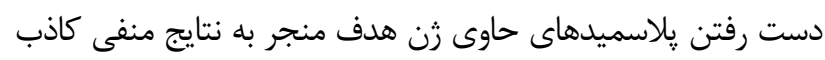

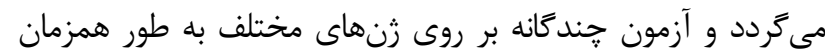

منجر به كاهش حساسيت مى گردد (Stewart et al., 2008).

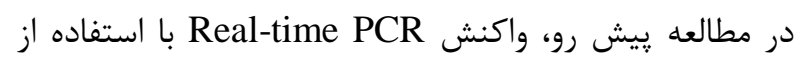

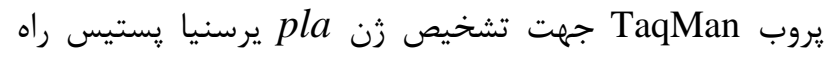

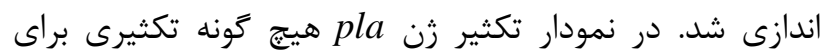

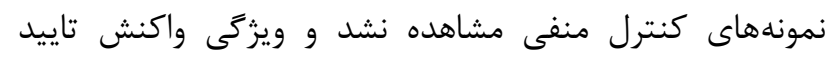

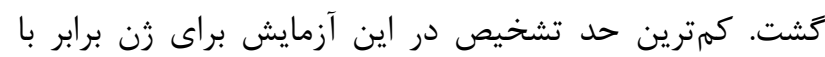

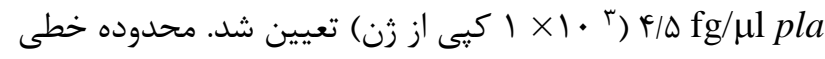

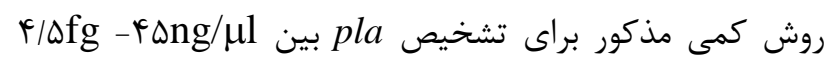

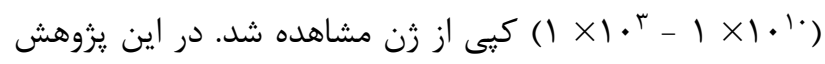

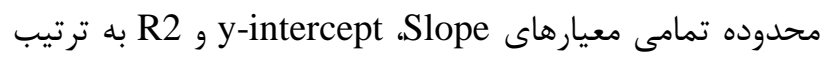

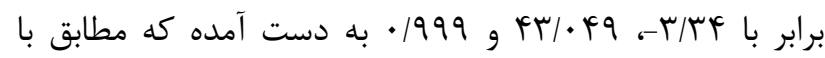

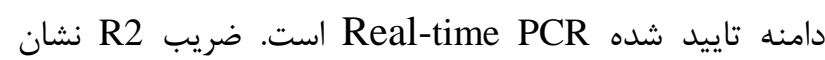
دهنده دقت و صحت در تهيه رقتهاى سريال و درستى ندانى

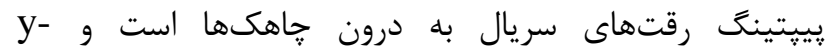
intercept

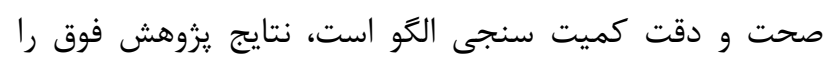

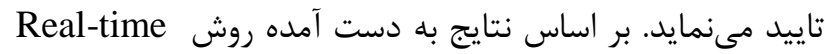

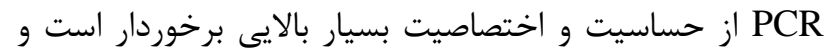

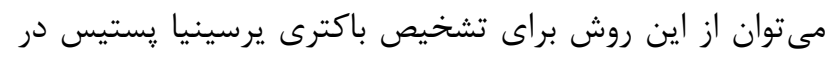

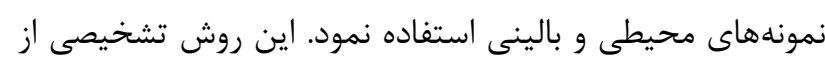

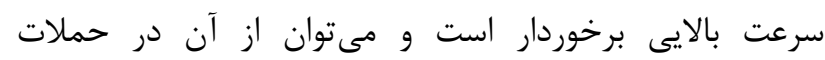
بيوتروريسمى و بررسى هاى إيبدميولوزيكى استفاده نمود.

\section{سياسگَزارى}

نويسندكان مقاله مراتب قدردانى خود را از كليه مسئولينى كه در دانشعاه علوم يزشكى آجا در انجام اين مطالعه همكارى نمودهاند، ابراز مى دارند.
نمونهاى مختلف بالينى، باستانى، كى و غيره استفاده كردهاند

.(Leal \& Almeida, 1999; Sergueev et al., 2010) نتايج مطالعهاى نشان داد: Real-time PCR ابزارى قدرتمند جهت تشخيص يرسينيا يستيس و يرسينيا سودوتوبر كلوزيس

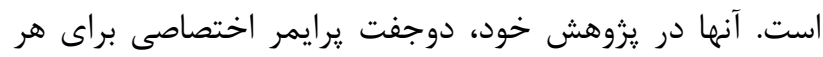

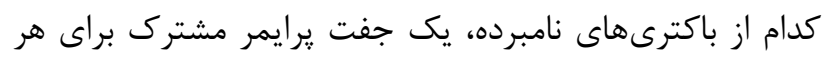

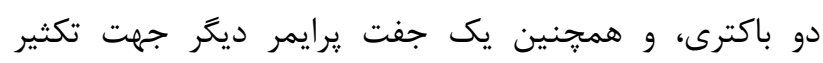

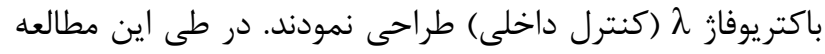

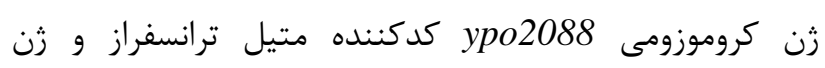

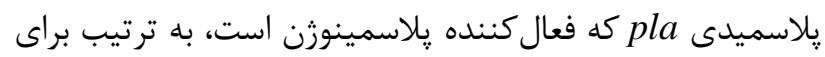

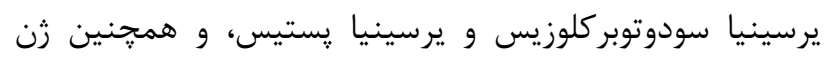

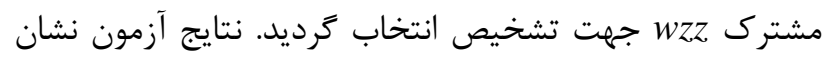

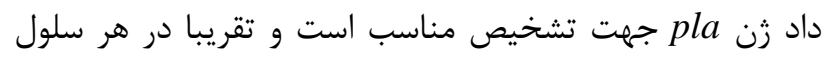

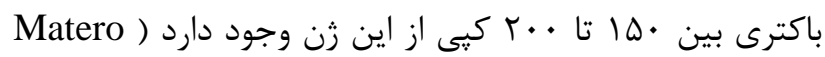
.et al., 2009 در طى مطالعهاى بر روى

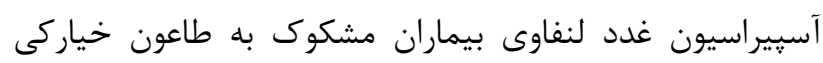
روش Real-time PCR ('ها نوكلئاز و يروب هيبريداسيون) با مئان

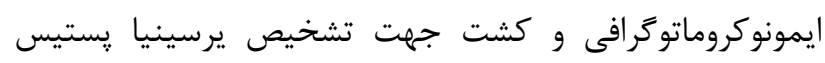

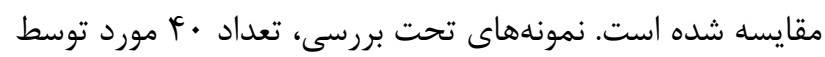

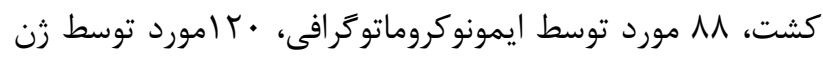

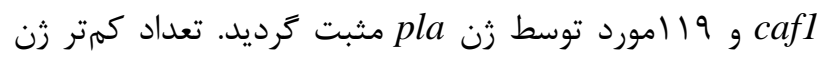
نسبت به cafl به دليل آ cafla

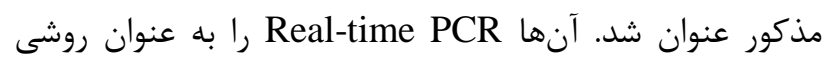
مناسب جهت تشخيص بيماران مشكوك به طندان طاعون خياركى

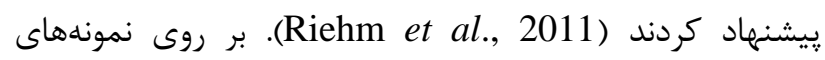

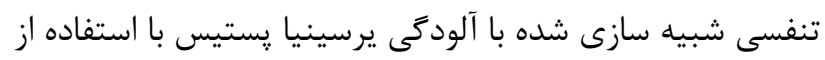
روش شده است. نتايج نشان داد در صورت عدم وجود مهاركننده در واكنش، اختصاصيت و حساسيت روش Real-time PCR

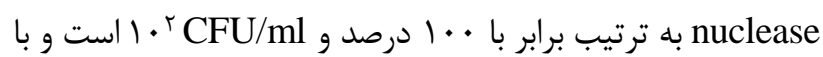

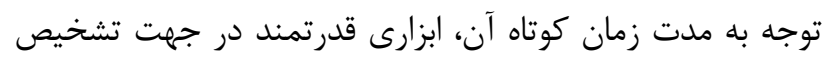

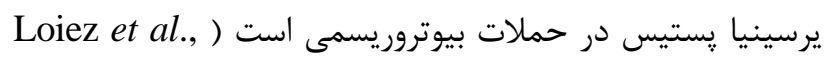

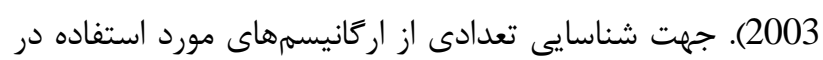
ساخت سلاحهاى زيستى از Real-time PCR استفاده شده است.

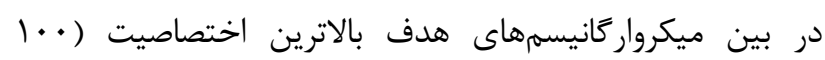

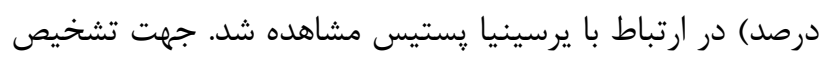

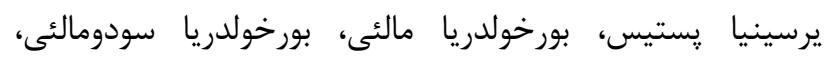

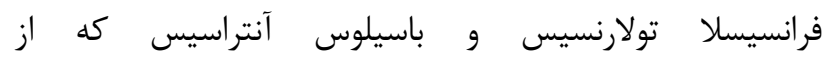
ميكرواركانيسمهاى با پِانسيل ساخت سلاحهاى زيستى هستند؛ 


\section{REFERENCES}

Arya, M., Shergill, I.S., Williamson, M., Gommersall, L., Arya, N. and Patel, H.R. 2005. Basic principles of real-time quantitative PCR. - Expert Rev. Mol. Diagn. 5: 209-219.

Ayyadurai, S., Flaudrops, C., Raoult, D. and Drancourt, M. 2010. Rapid identification and typing of Yersinia pestis and other Yersinia species by matrix-assisted laser desorption/ionization time-of-flight (MALDITOF) mass spectrometry. - BMC Microbiol. 10: 1-7.

Azizi, M.H. and Azizi, F. 2010. A history of the human plague in Iran. - Arch. Iran Med. 13: 563-569.

Chase, C.J., Ulrich, M.P., Wasieloski, L.P., Kondig, J.P., Garrison, J. and Lindler, L.E. 2005. Real-time PCR assays targeting a unique chromosomal sequence of Yersinia pestis. - Adv. Clin. Chem. 51: 1778-1785.

Drancourt, M. and Raoult, D. 2002. Molecular insights into the history of plague . - Microbes Infect. 4: 105109.

Engelthaler, D.M., Gage, K.L., Montenieri, J.A., Chu, M. and Carter, L.G. 1999. PCR detection of Yersinia pestis in fleas: comparison with mouse inoculation. J. Clin. Microbiol. 37: 1980-1984.

Esamaeili, S., Azadmanesh, K., Naddaf, S.R. Rajerison, M., Carniel, E. and Mostafavi, E. 2013. Serologic survey of plague in animals, western Iran. - J. Emerg. Infect. Dis. 19: 1549-1551..

Espy, M.J., Uhl, J.R., Sloan, L.M., Buckwalter, S.P., Jones, M.F., Vetter, E.A., Yao, J.D., Wengenack, N.L., Rosenblatt, J.E., Cockerill, F.R. and Smith, T.F. 2006. Real-time PCR in clinical microbiology: applications for routine laboratory testing. - Clin. Microbiol. Rev. 19: 165-256.

Filippov .A.A., Sergueev, K.V., He, Y., Huang, X.Z., Gnade, B.T. and Mueller, A.J. 2011. Bacteriophageresistant mutants in Yersinia pestis: identification of phage receptors and attenuation for mice. - PLOS ONE 6: 1-11.

Kenny, J.H., Zhou, Y., Schriefer, M.E. and Bearden, S.W. 2008. Detection of viable Yersinia pestis by fluorescence in situ hybridization using peptide nucleic acid probes. - J. Microbiol. Methods. 75: 293301.

Leal, N.C and Almeida, A.M. 1999. Diagnosis of plague and identification of virulence markers in Yersinia pestis by multiplex PCR. - Rev. Inst. Med. Trop. Sao Paulo. 41: 339-342.

Lindler, L.E., Fan, W. and Jahan, N. 2001. Detection of ciprofloxacin-resistantYersinia pestis by fluorogenic PCR using the light Cycler. - Eur. J. Clin. Microbiol. Infect. Dis. 39: 3649-3655.

Loiez, C., Herwegh, S., Wallet, F., Armand, S., Guinet, F. and Courcol, R.J. 2003. Detection of Yersinia pestis in sputum by real-time PCR. - Eur. J. Clin. Microbiol. 10: 190-212.

Mackay, I.M. 2004. Real-time PCR in the microbiology laboratory. - Clin. Microbiol. Infect. 10: 190-212.

Matero, P., Pasanen, T., Laukkanen, R., Tissari, P., Tarkka, E. and Vaara M. 2009. Real-time multiplex PCR assay for detection of Yersinia pestis and Yersinia pseudotuberculosis. - Apmis. 117:34-44.
O'Hara, C.M. 2005. Manual and automated instrumentation for identification of Enterobacteriaceas and other aerobic gram-negative bacilli. - Clin. Microbiol. Rev. 18: 147-162.

Perry, R.D. and Fetherston, J.D. 1999. Yersinia pestis etiologic agent of plague. - Clin. Microbiol. Rev. 10: 35-66.

Qu, S., Shi, Q,. Zhou, L., Guo, Z., Zhou, D. and Zhai, J. 2010. Ambient stable quantitative PCR reagents for the detection of Yersinia pestis. - PLOS ONE 4: 1-7.

Rachwal, P.A., Rose, H.L., Cox ,V., Lukaszewski, R.A., Murch, A.L. and Weller, S.A. 2012. The potential of TaqMan Array Cards for detection of multiple biological agents by real-time PCR. - PLOS ONE 7: $1-7$.

Riehm, J.M., Rahalison, L., Scholz, H.C., Thoma, B., Pfeffer, M. and Razanakoto, L.M. 2011. Detection of Yersinia pestis using real-time PCR in patients with suspected bubonic plague. - Mol. Cell Probes. 25: 812.

Rollins, S.E., Rollins, S.M. and Ryan, E.T. 2003. Yersinia pestis and the plague. - Am. J. Clin. Pathol. 119: 7885.

Schofield, D.A., Molineux, I.J. and Westwate, C. 2009. Diagnostic bioluminescent phage for detection of Yersinia pestis. - J. Clin. Microbiol. 47: 3887-3894.

Sergueev, K.V., Borschel, R.H., Nikolich, M.P. and Filippov, A.A. 2010. Rapid and sensitive detection of Yersinia pestis using amplification of plague diagnostic bacteriophages monitored by real-time PCR. - PLOS ONE 5: 1-10.

Stewart, A., Satterfield. B., Cohen, M., O'Neill, K. and Robison, R. 2008. A quadruplex real-time PCR assay for the detection of Yersinia pestis and its plasmids. J. Med. Microbiol. 57: 324-331.

Suzuki, S., Sakakibara, H. and Hotta, S. 1997. Latex agglutination tests for measurement of antiplague antibodies. - Eur. J. Clin. Microbiol. Infect. Dis. 6: 332-336.

Tomaso, H., Reisinger, E.C., Dahouk, S., Frangoulidis, D., Rakin., A. and Landt, O. 2006. Rapid detection of Yersinia pestis with multiplex real-time PCR assays using fluorescent hybridisation probes. - FEMS Immunol. Med. Microbiol. 38: 117-26.

Tomaso, H., Thullier, P., Seibold, E., Guglielmo, V., Buckendahl, A. and Rahalison, L. 2007. Comparison of hand-held test kits, immunofluorescence microscopy, enzyme-linked immunosorbent assay, and flow cytometric analysis for rapid presumptive identification of Yersinia pestis. - Eur. J. Clin. Microbiol. Infect. Dis. 45: 3404-3407.

Tomaso, H., Reisinger, E.C., Dahouk, S., Frangoulidis, D., Rakin, A. and Landt, O. 2003. Rapid detection of Yersinia pestis with multiplex real-time PCR assays using fluorescent hybridisation probes. - FEMS Microbiol. Immunol. 38: 117-126.

Wang, J.Z., Duan, R., Liang, J.R., Huang, Y., Xiao, Y.C, Qiu, H. and Wang, X. 2014. Real-time TaqMan PCR for Yersinia enterocolitica detection based on the ail and fox A Genes - Eur. J. Clin. Microbiol. Infect. Dis. 52: 4443-4444. 
Wilmoth, B.A., Chu, M.C. and Quan, T.J. 1996. Identification of Yersinia pestis by BBL crystal enteric / nonfermentor identification system. - Eur. J. Clin. Microbiol. Infect. Dis. 34: 2829-2830.

Woron, A.M., Nazarian, E.J., Egan, C., McDonough, K.A., Cirino, N.M. and Limberger, R.J. 2006. Development and evaluation of a 4-target multiplex real-time polymerase chain reaction assay for the detection and characterization of Yersinia pestis. Diagn. Microbiol. Infect. Dis. 56: 261-268

Zhang. Z., Liang. Y., Yu. D., Xia. L. and Hai. R. 2013. Development of a multiplex polymerase chain reaction (PCR) with an internal control method to detect Yersinia pestis in the plague foci surveillance. Afr. J. Microbiol. Res.7: 698-700.

How to cite this article:

Kabiri, Kh. and Majidzadeh, K. 2020. Molecular detection of causative agent of plague based on pla gene. - Nova Biol. Reperta 6: 374-381. (In Persian)

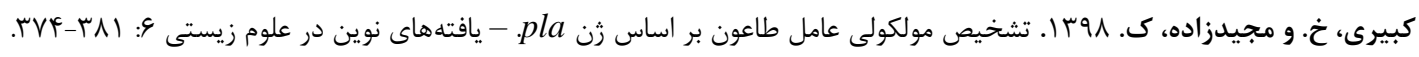

